\title{
Glycerol monooleate/solvents systems for progesterone transdermal delivery: in vitro permeation and microscopic studies
}

\author{
Gislaine R. Pereira ${ }^{1}$, John H. Collett ${ }^{2}$, Sérgio B. Garcia ${ }^{3}$, José A. Thomazini", \\ Maria Vitória Lopes Badra Bentley ${ }^{1 *}$ \\ ${ }^{1}$ Faculdade de Ciências Farmacêuticas de Ribeirão Preto, Universidade de São Paulo, Brasil, '²Department of \\ Pharmacy, University of Manchester, UK, ${ }^{3}$ Faculdade de Medicina de Ribeirão Preto, Universidade de São Paulo
}

*Correspondence:

M. V. L. B. Bentley

Faculdade de Ciências Farmacêuticas

de Ribeirão Preto

Universidade de São Paulo

Av do Café, s/n

14040-903, Ribeirão Preto, São Paulo, Brazil.

E-mail: vbentley@usp.br
Transdermal delivery of most drugs is precluded by the barrier characteristics of the stratum corneum (SC). Chemical penetration enhancers are capable of interacting with SC constituents, inducing a temporary reversible increase in the skin permeability. The aim of this work was to assess the influence of glycerol monooleate (GMO)/solvents systems on percutaneous absorption across hairless mouse SC of a lipophilic drug, progesterone (PG), as well as its effect on the SC structural characteristics, by scanning electron microscopy (SEM) and confocal laser scanning microscopy (CLSM). The morphological changes observed in the hairless mouse SC suggest a GMO effect on the skin barrier. In addition, the increase in the in vitro $P G$ flux and in vivo penetration of a fluorescent label point towards GMO as a potential absorption enhancer. The results obtained showed that GMO/solvents systems provoked changes in the SC that could be causing increased permeation of $P G$ across hairless mouse skin, optimising in this way the transdermal delivery of this drug.
Uniterms:

- Glycerol monooleate

- Penetration enhancer

- Scanning Electron

Microscopy

- Confocal Laser Scanning Microscopy

- In vitro permeation study

\section{INTRODUCTION}

The skin has attracted much attention as an alternative route for administering systemically active drugs. The potential advantages associated with transdermal drug delivery are well documented (Guy et al., 1987). However, very few drugs can be administered transdermally due to the low permeability of the skin, predominantly attributed to its outermost layer, the stratum corneum (SC), a multilayered wall-like structure in which keratin-rich corneocytes are embedded in an intercellular lipid-rich matrix. It has been assumed that the transport of substances across the SC occurs via both the intra and intercellular routes, the intercellular lipids being the most important for the percutaneous absorption of most permeants (Abraham et al., 1995).

Chemical and physical approaches to increase transdermal transport have been explored in efforts to enhance skin permeability and expand the range of drugs, which can be delivered transdermally (Chang et al., 2000; Obata et al., 2000; Sung et al., 2000). In theory, the rate of skin permeation of drugs can be increased either by varying vehicle composition in order to increase the solubility of drugs in the skin, or by altering skin permeability to the drug. In this case, chemical penetration enhancers have been extensively used. Ideally, an enhancer should be chemically and pharmacologically inert, non-toxic, nonirritant and non-allergenic. It might have a rapid and 
reversible onset of action, be potent at low concentrations and compatible with the formulation ingredients. Various vehicles have been identified as penetration enhancers. Many of these substances however, have been associated with untoward reactions such as acute and chronic inflammation of subcutaneous tissue. To overcome this problem, compounds that cause relatively less skin irritation have been studied as new candidates for percutaneous absorption enhancers, including natural components of skin lipids which have long-chain saturated or unsaturated fatty acids (Williams, Barry, 1992).

Glycerol monooleate (GMO) is a fusogenic and polar lipid of interest in a number of areas ranging from controlled uptake to release of cosmetic, food and pharmaceutical formulations (Qiu, Caffrey, 2000). It is capable of interacting with phospholipid bilayers and, like other lipids, has been proposed as a penetration enhancer (Maggio, Lucy, 1976; Ogiso et al., 1995).

In the present work, the influence of GMO on the percutaneous absorption of progesterone (PG) through hairless mouse skin was studied by evaluating in vitro permeation parameters. Morphological methods, such as scanning electron microscopy (SEM), which provide visualization of the structure of $\mathrm{SC}$, were useful to determine the influence of penetration enhancers on SC structure (Bentley et al., 1997). Confocal laser scanning microscopy (CLSM) was used to provide information about the in vivo penetration of a fluorescent label (fluorescein) across hairless mouse skin under the influence of GMO.

\section{MATERIALS AND METHODS}

\section{Chemicals}

Glycerol monooleate (GMO), progesterone (PG), fluorescein and type III trypsin were obtained from Sigma Chemical Co. (St. Louis, MO, USA). All the other chemicals used were of analytical grade; solvents used in HPLC were of HPLC grade.

\section{Preparation of hairless mouse SC samples for the pre- treatment and in vitro permeation studies}

Abdominal full-thickness skin was excised from male, one month old, HRS/J-Jackson Laboratories, Bar Harbor, ME hairless mice; subcutaneous fat and connective tissue were removed using forceps. The SC was prepared by floating abdominal full-thickness skin for $14 \mathrm{~h}$ on a water solution containing $0.1 \%(\mathrm{w} / \mathrm{v})$ trypsin and $0.5 \%(\mathrm{w} / \mathrm{v})$ sodium bicarbonate at room temperature. The mushy epidermis was removed by rubbing with moistened cotton tipped applicator. The transparent SC sheets obtained, were briefly rinsed with distilled water, blotted dry and kept in a desiccator until ready for use. SC sheets were examined in optical microscope in order to verify the presence of holes. Samples presenting holes were not used in the experiments.

\section{Pre-treatment procedure}

Hairless mouse SC sheets were hydrated by floating on phosphate buffered saline ( $\mathrm{pH} 7.2$ ) with stirring, for $3 \mathrm{~h}$ at $37{ }^{\circ} \mathrm{C}$. During this period, a formulation consisting of $20 \%$ (w/v) GMO in mineral oil was placed over the SC. Only mineral oil was also studied. After $3 \mathrm{~h}$, the $\mathrm{SC}$ sheets were rinsed with ethanol $(50 \% \mathrm{v} / \mathrm{v})$ and used for in vitro experiments. SC sheets without pre-treatment were used as controls. For each formulation, 10 hairless mouse SC sheets were used.

\section{In vitro permeation studies}

The in vitro permeation study was carried out at $37^{\circ} \mathrm{C}$, using ten modified Franz-type diffusion cells assembled with a hairless mouse SC sheet mounted between the donor and acceptor chambers. The receptor solution was $10 \%(\mathrm{v} / \mathrm{v})$ ethanol in distilled water, changed at each sampling time to maintain sink conditions. The donor solutions $[1 \mathrm{~mL}$ of saturated PG (infinite dose) in mineral oil containing 20\% (w/ v) GMO] were applied on upper surface of SC nonocclusively. Controls without GMO was also tested. Samples from the receptor phase were withdrawn at predetermined times and analysed by HPLC. When pre-treated hairless mouse SC sheets were used, the donor solutions were $1 \mathrm{~mL}$ of saturated solutions of PG in mineral oil.

\section{HPLC assay}

Analyses of all samples of the in vitro permeation studies were performed according to the method proposed by Pereira et al. (2000). A Shimadzu Instruments HPLC System, UV detector at $254 \mathrm{~nm}, \mathrm{C}_{18}$ reversed-phase column $125 \mathrm{~mm}$ x $4 \mathrm{~mm}(5 \mathrm{~mm}), \mathrm{C}_{18}$ pre-column $4 \mathrm{~mm} \mathrm{x}$ $4 \mathrm{~mm}(5 \mathrm{~mm})$ was used. A methanol:water (70:30) mixture was used as the mobile phase, at a flow rate of $1 \mathrm{~mL} / \mathrm{min}$ and an injection volume of $20 \mu \mathrm{L}$. The extraction was carried using chloroform. Medroxyprogesterone was the internal standard. The retention times were $8.0 \mathrm{~min}$ and $10.0 \mathrm{~min}$ for the internal standard and progesterone, respectively. The detection sensitivity of this HPLC method for progesterone was $300 \mathrm{ng} / \mathrm{mL}$, with less than $1 \%$ intra-day variation, and less than $3 \%$ inter-day variation. 


\section{Scanning electron microscopy (SEM)}

Freshly excised abdominal skin samples $\left(\sim 1 \mathrm{~cm}^{2}\right.$, $\mathrm{n}=6$ ) from hairless mice were incubated for $2 \mathrm{~h}$ at room temperature in $50 \%(\mathrm{v} / \mathrm{v})$ ethanol aqueous solution containing $20 \%(\mathrm{w} / \mathrm{v})$ GMO. After fixation with $3 \%(\mathrm{w} / \mathrm{v})$ glutaraldehyde in $0.1 \mathrm{M}$ sodium cacodylate buffer for $3 \mathrm{~h}$ and post-fixation with $1 \%(\mathrm{w} / \mathrm{v})$ osmium tetroxide for $2 \mathrm{~h}$, the samples were dried using increasing concentration of ethanol, coated with gold and viewed under a Jeol JSM Scanning Electron microscope. Approximately 10 skin samples were studied for each formulation. Control skins treated only with $50 \%(\mathrm{v} / \mathrm{v})$ ethanol water solution were also tested.

\section{Confocal laser scanning microscopy (CLSM)}

Formulations containing $100 \mu \mathrm{g} / \mathrm{mL}$ of the fluorescent label (fluorescein) and 20\% (w/v) GMO in a 50\% (v/v) ethanol water solution were applied on the dorsal region of the mice and left for $3 \mathrm{~h}$. The controls were untreated skin samples or skin treated with formulations without GMO. After the treatment, the animals $(n=6)$ were sacrificed by cervical dislocation and treated skin areas removed. A mechanical cross-section (perpendicular series) was made from the skin samples. The samples were embedded in a matrix, frozen at $-17^{\circ} \mathrm{C}$ and sectioned at $40 \mu \mathrm{m}$ thickness. To avoid interference by fluorescence from damaged cells, the mechanical cross-section of the skin was examined by CLSM, $10 \mu \mathrm{m}$ below the cutting surface (De Rosa et al.,
2000). A krypton-argon laser line at $488 \mathrm{~nm}$ was used for excitation; emission was detected at $530 \mathrm{~nm}$. Confocal Microscope LEICA-DMIRBE, software LEICA TSCNT 1.5.451, equipped with Kripton-Argon laser and a 16X immersion objective was used. To investigate the autofluorescence properties of the skin, samples were first observed in the absence of fluorescein. The autofluorescence of hairless mouse skin was found to be very low for the confocal settings used in this study. Because fluorescein is not chemically similar with PG, it was used only as fluorescent probe for visualization of GMO effect in the skin.

\section{Statistical analysis}

Statistical comparison was made using the nonparametric Kruskal-Wallis test and Dunn's multiple range test with the help of an SAS program. The level of significance was taken as $P<0.05$.

\section{RESULTS AND DISCUSSION}

In this work the potential use of GMO/solvents systems for PG transdermal delivery, a lipophilic model drug, was investigated. The influences of GMO in mineral oil and pre-treatment on the in vitro percutaneous absorption profiles of $\mathrm{PG}$ across hairless mouse SC are shown in Figure 1. A linear relationship was obtained when the total amount of progesterone in the receptor phase was plotted against time. GMO/mineral oil systems

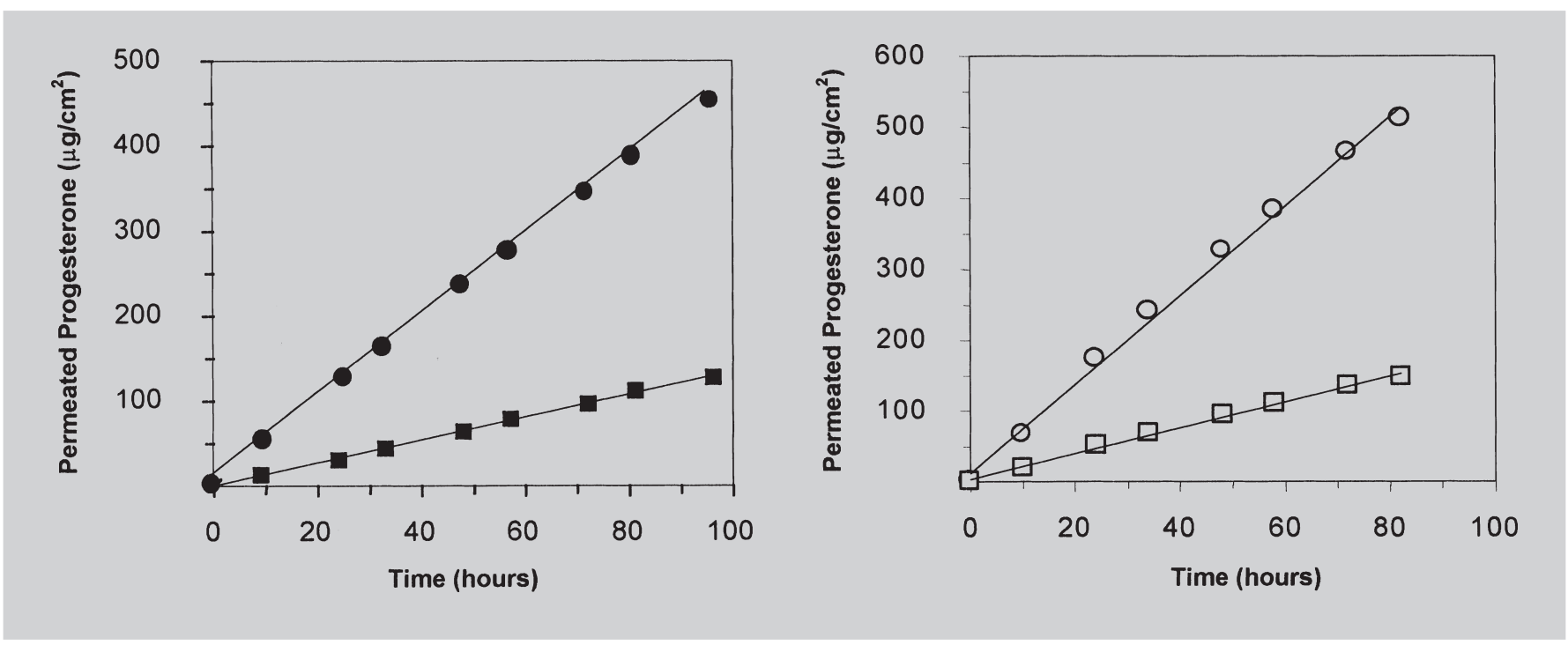

FIGURE 1 - In vitro permeation of progesterone across hairless mouse SC: (a) from $(\bullet) 20 \%$ (w/w) GMO in mineral oil (匹) mineral oil (control); (b) following the pre-treatment with (O) 20\% (w/w) GMO in mineral oil ( $\square$ ) mineral oil (control). SC: stratum corneum; GMO: glycerol monooleate. 
increased the PG flux with or without the pre-treatment with these systems (Table 1). The linear relationship observed in the Figure 1 suggests that the percutaneous transport of PG from GMO in mineral oil across hairless mouse SC followed zero order kinetics. PG fluxes were significantly greater $(P<0.05)$ than the control. The increase of $\mathrm{PG}$ permeation can be mainly ascribed to the enhancer effect of GMO/mineral oil system and not to the increase of the drug solubility in the system, since saturated preparations of PG were used (Table I). In addition, the pre-treatment experiments showed that $\mathrm{GMO} /$ mineral oil systems might have caused changes on the hairless mouse SC, which provoked an increase on the PG flux (about 4.5 times compared to controls). Since the permeability of lipophilic drugs through human skin has been found to be slightly higher than in hairless skin (Morimoto et al., 1991), a greater permeation rate might be expected in man. The profound hydration effect on skin or SC under in vitro experimental conditions must also be considered (Scheuplein et al., 1969). Nevertheless, our results are still very useful, because tissue is hydrated easily, and more under occlusion, than in most drug transdermal administrations (patch) (Guy et al., 1987).

The mechanism of topical delivery involves mainly the direct transfer of drugs to the lipid phase of the SC (Golden et al., 1987). The SC lipids are arranged in multiple bilayers providing alternate hydrophobic and hydrophilic barriers (Abraham et al., 1995). In general, routes of skin penetration are classified into two pathways, polar and non-polar in the intercellular domain. In a study of the action of enhancers on transdermal delivery, Ogiso et al. (1995) observed that GMO and oleic acid increased the flux across skin of a lipophilic drug (indomethacin) and of a hydrophilic drug (urea), and also the fluidity of SC lipids.

Fatty acids are the most abundant lipids in biological membranes, where they exist in free form but also as components of more complex lipids such as ceramides, triglycerides and phospholipids. Administration of exogenous free fatty acids, mainly of the cis-unsaturated variety, has been reported to increase membrane permeability (Potts et al., 1991; Tanojo et al., 1997; Gao, Singh, 1998). GMO has a similar structure to oleic acid, with a cis-unsaturated double bound in the molecule. It was initially proposed that the presence of $c$ is double bounds introduces an accentuated flexion of the hydrocarbon chain, which prevents the formation of wellordered compact crystals (Golden et al., 1986). Results obtained by attenuated total reflectance infrared spectroscopy ATIR suggest that the action of oleic acid could be due to two mechanisms, lipid fluidity and lipid phase separation (Tanojo et al., 1997). It has been proposed that lipids like oleic acid and GMO which have a polar head and a carbon chain presenting a low melting point increase membrane permeability by promoting intercellular lipid disorder (Ogiso et al., 1995) and interactions between a hydroxyl group of GMO and the anionic oxygen in the polar head of phospholipids (Maggio, Lucy, 1976).

Morphological methods for visualization of the structures of SC such as SEM are useful for the determination of the structural changes caused by different types of penetration enhancer and the impact of different types of vehicle on SC membrane structure (Bentley et al., 1997; Pflucker et al., 1999). In fact, the present SEM studies showed some changes occurred in the intercellular space among the corneocytes for all skin samples treated with GMO formulation (Figure 2).

The corneocytes appear in their characteristic polygonal shape and seem to be intact, and judging from the intercellular spaces, to lie very close to each other (Figure $2 \mathrm{a}$ and $2 \mathrm{~b}$ ). Treatment with GMO/ethanol aqueous solution caused a change in the intercellular regions; junctions between the cells were loosened, leading to increased cell separation (Figure $2 \mathrm{c}$ and $2 \mathrm{~d}$ ). Considering the resolution characteristics of SEM technique, it can be

TABLE I - Influence of GMO/mineral oil on in vitro permeation of progesterone across hairless mice stratum corneum*

\begin{tabular}{lccc}
\hline Formulation & $\begin{array}{c}\text { Progesterone } \\
\text { concentration** } \\
(\mathrm{mg} / \mathrm{mL})\end{array}$ & $\begin{array}{c}\text { Flux } \\
\left(\mu \mathrm{g} / \mathrm{cm}^{2} \cdot \mathrm{h}^{-1}\right)\end{array}$ & $\begin{array}{c}\text { Flux after } \\
\text { pre-treatment*** } \\
\left(\mu \mathrm{g} / \mathrm{cm}^{2} \cdot \mathrm{h}^{-1}\right)\end{array}$ \\
\hline $20 \%(\mathrm{w} / \mathrm{w})$ GMO in mineral oil & 3.5 & $4.7( \pm 0.1)$ & $6.3( \pm 0.32)$ \\
Mineral oil (Control) & 1.2 & $1.4( \pm 0.07)$ & $1.8( \pm 0.08)$ \\
\hline
\end{tabular}

\footnotetext{
* Data refer to means \pm SEM of 10 experiments. Non parametric Kruskal-Wallis statistical analysis: $P<0.05$ significant;

** Saturated PG solutions; *** Pre-treatment period: 3 h; formulation applied after pre-treatment: saturated PG solutions. GMO: glycerol monooleate.
} 
suggested the effect of GMO on the SC junction, which is mainly formed by lipids. Because of the atoxicity of GMO, even for food use, and the constant turn over of the skin in vivo these changes caused by GMO should not be considered a problem for human use.

CLSM has been used to localize the transport pathways of the macromolecules and fluorescent labels in the skin after electroporation, iontophoresis and application of liposomes and absorption enhancers, to assess the effect of these methods on increasing (trans) dermal and transmucosal transport (Marttin et al., 1997; Van Kuijk-Meuwissen et al., 1998; Kirjawainen et al., 1999; Lombry et al., 2000). The CLSM images parallel to the surface of the skin provide information about the distribution pattern of the fluorescent marker in the SC. In this way, the penetration profiles of the label into the skin can be compared after application of different formulations. In order to obtain information about the penetration of a fluorescent label into deeper layers of the skin, cross-sections perpendicular to the skin were required and subsequently collecting of CLSM images parallel to the plane of these sections.

In the present study fluorescein was used only as a fluorescent probe and no longer can be related to $\mathrm{PG}$ penetration. The information that CLSM gives is only about the effect of GMO on the skin, altering its barrier
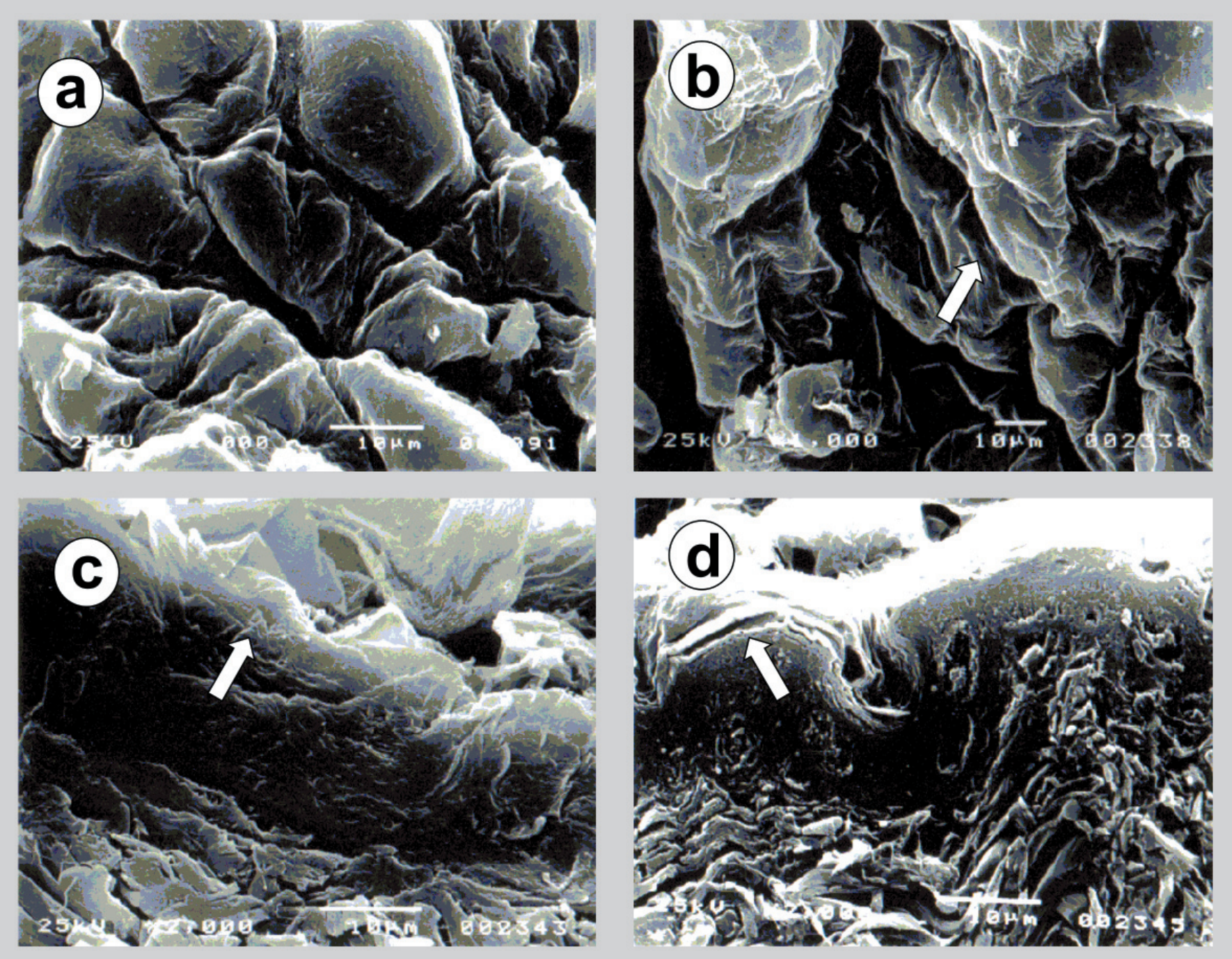

FIGURE 2 - Scanning electron micrographs of hairless mouse SC: (a) surface of SC control (2,000X); (b) surface of SC treated with $20 \%(\mathrm{w} / \mathrm{v}) \mathrm{GMO}$ in $50 \%(\mathrm{v} / \mathrm{v})$ ethanol water solution $(2,000 \mathrm{X})$; (c) transverse section of SC control $(2,000 \mathrm{X})$; (d) transverse section of SC treated with $20 \%(\mathrm{w} / \mathrm{v}) \mathrm{GMO}$ in $50 \%(\mathrm{v} / \mathrm{v})$ ethanol water solution $(4,000 \mathrm{X})$. Bar indications represent $10 \mathrm{~mm}$. SC: stratum corneum; GMO: glycerol monooleate. 
effect. As shown in Figure 3, the extent of penetration of fluorescein into the skin after $3 \mathrm{~h}$ was visualized by CLSM. This method resulted in images in which the SC, viable epidermis and dermis are visualized in the same focal plane, without a decrease in intensity due to intervening layers of tissue.

Only a slight fluorescent band was observed on the surface of the skin after treatment with fluorescein in the absence of GMO (Figure 3b). When GMO was presented in the formulation, fluorescence spread deeply reached the viable epidermis and dermis (Figure 3c). Confocal microscopy studies showed, therefore, that skin penetration of fluorescein increased remarkably after treatment with GMO.

\section{CONCLUSIONS}

Lipids have been studied as potential absorption enhancers for transdermal drug delivery. Considering the non-toxicity of GMO even for internal use and in vitro permeation enhancement found in this and other work (Ogiso et al., 1995), it can be proposed as a promising skin absorption enhancer. Additionally, our results of SEM and CLSM in animal model provided understandings about the effects of GMO on the SC and in vivo fluorescent probe penetration into the skin, respectively. The present data, while needing further validation by experiments on human skin indicate the possibility of using GMO as an absorption enhancer. Further studies, now in progress, will


FIGURE 3 - Confocal images of mechanical cross-sections (perpendicular series) of hairless mouse skin, optically sectioned $10 \mathrm{~mm}$ below the cutting surface: (a) control (untreated skin); skin treated with: (b) $50 \%$ (v/v) ethanol water solution (control): (c) 20\% (w/w) GMO in 50\% (v/v) ethanol water solution. Both formulations contained $100 \mathrm{mg}$ fluorescein/mL. Bar indications represent $100 \mathrm{~mm}$. SC: stratum corneum; GMO: glycerol monooleate. 
be addressed to the evaluation of absorption enhancer effect of GMO for drugs with a range of lipophilicity as well as to elucidate the GMO concentration and time of application influences in this effect by in vitro permeation and in vivo confocal microscopy studies.

\section{ACKNOWLEDGMENTS}

The authors would like to thank Mrs. Maria Dolores Seabra Ferreira and Mrs. Márcia Sirlene Zardin Graeff (Department of Morphology, Faculty of Medicine of Ribeirão Preto, University of São Paulo) for assistance with SEM and CLSM studies, respectively. The authors are also thankful to FAEPA. This research was supported by FAPESP, Brazil.

\section{RESUMO}

\section{Sistemas monoleína/solventes para a liberação transdérmica da progesterona: estudos de permeação cutânea e microscópicos}

A liberação transdérmica de muitos fármacos é dificultada pelas características de barreira do estrato córneo. Promotores químicos de absorção cutânea são capazes de interagir com os constituintes do estrato córneo, induzindo aumento temporário e reversivel na permeabilidade da pele. O objetivo deste trabalho foi avaliar a influência de sistemas monoleina (monoleato de glicerol)/solventes na absorção percutânea de um fármaco lipofilico (a progesterona), através do estrato córneo de camundongos sem pelo, bem como o efeito da monoleina nas características estruturais do estrato córneo, por meio de microscopia eletrônica de varredura (SEM) e microscopia de varredura confocal a laser (CLSM). As alterações morfológicas observadas no estrato córneo de camundongos sem pelo sugerem efeito da monoleina na barreira da pele. E, ainda, o aumento no fluxo in vitro da progesterona, bem como na penetração in vivo do marcador fluorescente (fluoresceina), apontam a monoleína como potencial promotor de absorção cutânea. Os resultados obtidos mostraram que os sistemas monoleina/solventes provocaram alterações na estrutura do estrato córneo, que poderiam causar o aumento da permeação da progesterona através da pele de camundongos sem pelo, otimizando, deste modo, a liberação transdérmica deste fármaco.

UNITERMOS: Monoleina. Promotor de absorção cutânea. Microscopia eletrônica de varredura. Microscopia de varredura confocal a laser. Permeação in vitro.

\section{REFERENCES}

ABRAHAM, M. H., CHANDHA, H. S., MITCHELL, R.G. The Factors that influence skin penetration of solutes. J.Pharm. Pharmacol., London, v. 47, p. 8-16, 1995.

BENTLEY, M. V. L. B., VIANNA, R. F., WILSON, S., COLLETT, J. H. A characterization of the incluence of some cyclodextrins on the stratum corneum from the hairless mouse. J. Pharm. Pharmacol., London, v. 49, p. 397-402, 1997.

CHANG, S., HOFMANN, G. A., ZHANG, L., DEFTOS, L. J., BANGA, A. K. The effect of electroporation on iontophoretic transdermal delivery of calcium regulating hormones. J. Control. Rel., Amsterdam, v. 66, p. 127$133,2000$.

DE ROSA, F. S., MARCHETTI, J. M., THOMAZINI, J. A., TEDESCO, A. C., BENTLEY, M. V. L. B. A vehicle for photodynamic therapy of skin cancer: influence of dimethylsulphoxide on 5-aminolevulinic acid in vivo cutaneous permeation and in vivo protoporphyrin accumulation determined by confocal microscopy. $J$. Control. Rel., Amsterdam, v. 65, p. 359-366, 2000.

GAO, S., SINGH, J. Effect of oleic acid/ethanol and oleic acid/propylene glycol on the in vivo percutaneous absorption of 5-fluorouacil and tamoxifen and the macroscopic barrier property of porcine epidermis. Int. J. Pharm., Amsterdam, v. 165, p. 45-55, 1998.

GOLDEN, G. M., GUZEK, D. B., HARRIS, R. R., MCKIE, J. E., POTTS, R. O. Lipid thermotropic transitions in human stratum corneum. J. Invest. Dermatol., New York, v. 86, p. 255-259, 1986.

GOLDEN, G. M., GUZEK, D. B., MCKIE, J. E., POTTS, R. $\mathrm{O}$. The role of stratum corneum lipid fluidity in transdermal drug flux. J. Pharm. Sci., Washington, v. 76, p. 25-31. 1987.

GUY, R.H., HADGRAFT, J., HINZ, R.S., ROSKOS, K.V., BUCKS, D.A.W. In: CHIEN, Y.W. ed, Transdermal Controlled Systemic Medications. New York: Marcel Dekker, 1987. p. 179

KIRJAVAINEN, M., URTTI, A., VALJAKKA-KOSKELA, R., KIESVAARA, J., MONKKONEN, J. Liposome-skin interactions and their effects on the skin permeation of drugs. Eur. J. Pharm. Sci., Amsterdam, v. 7, p. 279-286, 1999. 
LOMBRY, C., DUJARDIN, N., PRÉAT, V. Transdermal Delivery of Macromolecules Using Skin Electroporation. Pharm. Res., New York, v. 17, p. 32-37, 2000.

MAGGIO, B.,LUCY, J. A polar-group behaviour in mixed monolayers of phospholipids and fusogenic lipids. Biochem.J., London, v. 155, p. 353-364, 1976.

MARTTIN, E., VERHOEF, J. C., CULLANDER, C., ROMEIJN, S. G., NAGELKERKE, J. F., MERKUS, F. W. H. M. Confocal Laser Scanning Microscopic visualization of the transport of dextrans after nasal administration to rats: effects of absorption enhancers. Pharm. Res., New York, v. 14, p. 631-637, 1997.

MORIMOTO, Y., HATANAKA, T., SUGIBAYASHI, K., OMIYA, H. Prediction of skin permeability of drugs: comparison of human and hairless rat skin. J. Pharm. Pharmacol., London, v. 44, p. 634-639, 1991.

OBATA, Y., SATO, H., JIE LI, C., TAKAYAMA, K., HIGASHIYAMA, K., NAGAI, T., ISOWA, K. Effect of synthesized cyclohexanol derivatives using L-menthol as a lead compound on the percutaneous absorption of ketoprofen. Int. J. Pharm., Amsterdam, v. 198, p. 191200, 2000.

OGISO, T., IWAKI, M., PAKU, T. Effect of various enhancers on transdermal penetration of indomethacin and urea, and relationship between penetration parameters and enhancement factors. J. Pharm. Sci., Washington, v. 84, p. 482-488, 1995.

PEREIRA, G. R., MARCHETTI, J. M., BENTLEY, M. V. L. B. A rapid method for determination of progesterone by reversed-phase liquid chromatography from aqueous media. Anal. Lett., New York, v. 33, p. 881-889, 2000.

PFLUCKER, F., HOHENBERG, H., HOLZLE, E., WILL, T., PFEIFFER, S., WEPF, R., DIEMBECK, W., WENCK , H., GERS-BARLAG, H. The outermost stratum corneum layer is an effective barrier against uptake of topically applied micronized titanium dioxide. Int. J. Cosmetic Sci., London, v. 21, p. 399-411, 1999.
POTTS, R. O., GOLDEN, G. M., FRANCOEUR, M. L., MAK, V. H. W., GUY, R. H. Mechanism and enhancement of solute transport across the stratum corneum. J. Control. Rel., Amsterdam, v. 15, p. 249-260, 1991.

QIU, H., CAFFREY, M. The phase diagram of the monoolein/water system: metastability and equilibrium aspects. Biomaterials, Oxford, v. 21, p. 223-234, 2000.

SCHEUPLEIN, R. J., BLANK, I. H., BRAUNER, M. D., MACFARLANE, D. J. Percutaneous absorption of steroids. J. Invest. Dermatol., New York, v. 52, p. 63-70, 1969.

SUNG, K. C., FANG, J., YOA-PU HU, O. Delivery of nalbuphine and its prodrugs across skin by passive diffusion and iontophoresis. J. Control. Rel., Amsterdam, v. 67, p. $1-8,2000$.

TANOJO, H., JUNGINGER, H. E., BODDÉ, H.E. In vivo human skin permeability enhancement by oleic acid: transepidermal water loss and Fourier-transform infrared Spectroscopy studies J.Control. Rel., Amsterdam, v. 47, p. 31-39, 1997.

VAN KUIJK-MEUWISSEN, M. E. M. J., MOUGIN, L., JUNGINGER, H. E., BOUWSTRA, J.A. Application of vesicles to rat skin in vivo: a confocal laser scanning microscopy study. J. Control. Rel., Amsterdam, v. 56, p. 189-196, 1998.

WILLIAMS, A. C., BARRY, B. W. Skin absorption enhancers. Crit. Rev. Ther. Drug Carrier Syst., Boca Raton, v. 9, 1992. p. 305- 353.

Recebido para publicação em 12 de setembro de 2001. 